\title{
HEJT JAKO ŹRÓDŁO SYTUACJI KRYZYSOWYCH PODMIOTÓW W PRZESTRZENI SPOŁECZNEJ
}

\section{Abstract \\ HATE SPEECH AS A SOURCE OF CRISIS SITUATIONS OF ENTITIES IN THE SOCIAL SPACE}

The discourse of public space has been brutalizing for years. The lack of social reactions, including media, which can be a sign of a kind of acceptance of the phenomenon, as well as a low level of legal responsibility, means that the communication of entities (companies, political parties and other organizations) in the social space goes far beyond the norms understood as the cultural construction of messages and creating a dialogue to implement the mission and goals of the entity. Therefore, it becomes important to determine how you can manage crisis communication to stabilize the entity's situation. It is worth referring to the typology of crisis management in the social media space of W.T. Coombs assumes three levels of attribution of the subject's responsibility, namely: the subject is a victim of a crisis, the subject has caused the crisis unknowingly and the subject has caused the crisis knowingly. In such a defined environment, the specificity of the hate should also be taken into account due to its subject, the subject of the hate and the author, and properly anticipate the effects of the hate in the context of managing the crisis situation of the entity, which will allow to choose the appropriate strategy of actions. Finally, it is necessary to indicate ways of reacting to the hate by the entities affected by it in the sphere of prevention and possible actions in the event of a hate crisis.

Key words: hate, crisis, media, communication, management

\section{Wprowadzenie}

Dyskurs przestrzeni publicznej od lat ulega brutalizacji. Brak reakcji społecznych, w tym medialnych, mogący świadczyć o swego rodzaju akceptacji zjawiska, przeświadczenie o anonimowości internetu, jak również niski poziom odpowiedzialności 
prawnej powodują, że komunikacja $\mathrm{w}$ mediach społecznościowych (social media, SM) znacznie wykracza poza normy rozumiane jako kulturalne konstruowanie przekazów i tworzenie dialogu w celu realizacji misji i celów organizacji. W tak zmieniającej się przestrzeni medialnej podmioty (osoby publiczne, firmy, partie polityczne i inne organizacje) narażone są na komunikację wykraczającą poza przyjęte normy społecznego komunikowania się, która może być źródłem sytuacji problematycznych, a w skrajnych przypadkach - sytuacji kryzysowych.

Należy mieć na względzie, że hejt wobec podmiotów w przestrzeni społecznej może przybierać wymierną formę. Jak podaje serwis Newseria, według badań „przeciętny koszt związany z sytuacją kryzysową w średniej lub małej firmie to między 50000 a 200000 funtów. (...) Duże przedsiębiorstwa ponoszą straty w wysokości od miliona do dwóch milionów, w zależności od tego, jak długo trwa kryzys"'.

Zakres zadań zawodowych zakładający profesjonalizm osób odpowiedzialnych za komunikowanie się podmiotów $\mathrm{z}$ otoczeniem zewnętrznym oraz prowadzenie komunikacji wewnętrznej wymaga działania według strategii (dobrą praktyką jest, aby była ona spójna ze strategią zarządczą organizacji), co w konsekwencji powinno oznaczać planowanie, wdrażanie oraz ewaluację działań. Tak pojmowane komunikowanie się podmiotu staje się wówczas elementem wypełnienia funkcji zarządzania.

Profesjonalne komunikowanie się podmiotu wymaga uwzględnienia warunków zakłócających komunikację, które w rezultacie mogą wpłynąć na destabilizację dowolnej sfery działania podmiotu (np. uzyskiwanie efektów ekonomicznych, naruszenia w obrębie wizerunku i reputacji podmiotu, destabilizacja finansowa, organizacyjna i in.).

Warto także zauważyć, że ryzyko wystąpienia hejtu wobec podmiotu jest niezależne od jego obecności i działalności w przestrzeni mediów społecznościowych. Poziom aktywności podmiotu w mediach społecznościowych może korelować z ryzykiem wystąpienia hejtu i jego intensywnością, ale też brak aktywności lub brak obecności w mediach społecznościowych nie stanowi gwarancji pozostawania poza działaniami agresora-hejtera. Dlatego zarządzając komunikowaniem się podmiotu, warto zadbać o przygotowanie podmiotu na wypadek hejtu, co w praktyce oznacza opracowanie działań zarządczych minimalizujących ryzyko pojawienia się hejtera w otoczeniu podmiotu oraz destabilizacji działań podmiotu, jego wizerunku i reputacji, a także dających możliwość podjęcia działań zaradczych.

Wobec tak określonych warunków zostały wyznaczone następujące cele wywodu:

1. Określenie sposobów zarządzania komunikacją w sytuacji kryzysowej w celu stabilizacji sytuacji podmiotu (funkcja prewencyjna zarządzania).

2. Określenie specyfiki hejtu ze względu na jego tematykę, podmiot hejtu i autora oraz przewidywane skutki hejtu w kontekście zarządzania sytuacją kryzysową (dobór odpowiedniej strategii działań).

1 Zob. https://biznes.newseria.pl/news/hejt-staje-sie-duzym,p120478802 (dostęp: 2.05.2019). 
3. Określenie sposobów reagowania na hejt przez podmioty nim dotknięte w sferze prewencji oraz podejmowania możliwych działań w sytuacji kryzysowej wywołanej hejtem.

W dobie możliwości znacznej dystrybucji przekazów kwalifikowanych jako hejt ryzyko wystąpienia zdarzeń mogących stanowić sytuację kryzysową organizacji wzrasta. Autorka artykułu, prowadząc badania dotyczące zarządzania sytuacjami kryzysowymi, jak również praktykę w tym zakresie, zauważyła wzrastającą liczbę takich zdarzeń oraz ich rosnącą siłę oddziaływania na podmioty hejtu. Przedstawione w tym artykule refleksje są wynikiem obserwacji dyskursu w przestrzeni publicznej oraz analizy problemu z wykorzystaniem metod: analizy zawartości mediów (content analysis) i analizy danych zastanych (desk research). Całość wywodu, poza odniesieniem do komunikacji społecznej i zarządzania sytuacjami kryzysowymi, zawiera także nawiązania do obszaru agresji elektronicznej.

Docelowo pogłębiona i rozszerzona analiza sytuacji kryzysowych organizacji, w których kryzys pierwotny lub wtórny wywołany został przez przekazy kwalifikowane jako hejt, w przyszłości będzie stanowić podstawę badania jakościowego. Celem badania będzie stworzenie modelu zarządzania komunikacją organizacji zarówno w sferze prewencji, jak i kryzysu właściwego.

\section{Sytuacje kryzysowe organizacji}

Rozważając tematykę sytuacji kryzysowej, literatura przedmiotu operuje wieloma pojęciami będącymi określeniem sytuacji naruszającej stabilność podmiotu. Wśród nich znajdziemy między innymi takie terminy jak: problem, konflikt, kryzys, sytuacja trudna ${ }^{2}$. Część literatury przedmiotu, jak również ekspertów jest zdania, że procedury zarządcze powinny być wykorzystywane dopiero wówczas, gdy problem, konflikt czy sytuacja trudna przejdzie w obszar kryzysu lub sytuacji kryzysowej. Jak jednak w pełni odpowiedzialnie wykluczyć te problemy czy konflikty, których nie warto ujmować w ramach procedur zarządczych? A może bezpieczniej - ujmując to w perspektywie potencjału ryzyka kryzysowego - każde zdarzenie naruszające stabilne funkcjonowanie podmiotu obejmować procedurami zarządzania sytuacjami kryzysowymi?

Odpowiedzi na tak postawione pytania nie są oczywiste, ponieważ konsekwencją odpowiedzi negatywnej mogą być zdarzenia, które - wobec braku podjęcia działań zarządczych - pozwalają na przekształcenie się sytuacji trudnej w sytuację kryzysową, a w dalszej kolejności w kryzys. Gdyby jednak odpowiedź była pozytywna, konsekwencją powinno być wdrożenie działań zarządczych, takich jak ${ }^{3}$ :

2 Dyskusja na temat określeń sytuacji stanowiących zagrożenie w: M. Kaczmarek-Śliwińska, Public relations organizacji w zarządzaniu sytuacjami kryzysowymi organizacji. Sztuka komunikowania się, Difin, Warszawa 2015, s. 49-51.

3 Tamże, s. 100-101. 
1. Identyfikacja potencjalnych sytuacji kryzysowych mogących stanowić zagrożenie dla stabilności dowolnego obszaru podmiotu.

2. Przygotowania manuala zarządzania kryzysowego uwzględniającego powyższe.

3. Szkolenia odnoszące się do działań zarządczych w potencjalnej sytuacji kryzysowej.

4. Opracowanie zestawu działań pokryzysowych.

W sytuacji, gdy przestrzeń komunikacyjna podmiotu obejmuje między innymi media instytucjonalne (prasa, radio, telewizja) oraz media społecznościowe, trudność w określeniu potencjalnych ryzyk znacznie wzrasta. O ile w sytuacji komunikowania się w obszarze mediów instytucjonalnych można było traktować konstruowanie i dystrybucję przekazów jako częściowo będące pod kontrolą (np. komunikaty przekazywane mediom przez podmioty czy funkcja gatekeepingu ze strony mediów), o tyle w sytuacji konstruowania i dystrybucji przekazów w przestrzeni mediów społecznościowych możliwość kontroli nad przekazem kończy się w momencie opublikowania w SM. Oznacza to, że część komunikacji podmiotu może podlegać różnym aktywnościom internautów, które nie zostały uzgodnione $\mathrm{z}$ podmiotem, nie są wykonywanie na jego zlecenie oraz $\mathrm{w}$ jego imieniu, nie muszą być zgodne $\mathrm{z}$ intencjami podmiotu, mogą negatywnie wpływać na jego wizerunek, a w sytuacjach skrajnych zostały zaplanowane jako działania mające w sposób celowy wyrządzić krzywdę podmiotowi.

Wobec tego warto rozważyć, czy działania zarządcze w zakresie sytuacji kryzysowej nie powinny być wdrażane w momencie, gdy podmiot dotykają sytuacje: poważnego zagadnienia (zdarzenia nadzwyczajnego, innego niż rutynowo podejmowane działania), zadań wymagających rozwiązań niestandardowych, zmian otoczenia podmiotu (zmian wewnętrznych lub zewnętrznych - zmian w branży, w przestrzeni prawnej, w strukturze organizacyjnej podmiotu itp.), a sama sytuacja wywołuje niepokój, niezadowolenie, trudności, obserwację podmiotu przez odbiorców (interesariuszy), negatywne reakcje otoczenia (wewnętrznego lub zewnętrznego), krytykę podmiotu, zainteresowanie mediów (zarówno instytucjonalnych, jak i społecznościowych).

Jak wynika z powyższego, zmiennych mogących wpłynąć na destabilizację działalności podmiotu może być wiele, a dodając do tego znaczną interaktywność przestrzeni medialnej, trudny do określenia staje się potencjał ryzyka. Mamy wówczas do czynienia z przypadkiem, gdy „różnorodność sytuacji, okoliczności, wpływu czynników wewnętrznych i zewnętrznych, zależnych i niezależnych od organizacji, może postawić organizację w sytuacji, gdy pozornie mały problem wywoła stan naruszający jej równowagę, czy też odwrotnie - zdarzenie postrzegane jako niosące pewne zagrożenie dla organizacji przechodzi niezauważenie, nie wyrządzając żadnych negatywnych skutków"4.

4 Tamże, s. 50. 
Dlatego też można przyjąć, że „zarządzanie sytuacją kryzysową oznacza działania podejmowane $\mathrm{w}$ zakresie prewencji kryzysu, a obejmujące przewidywanie potencjalnych sytuacji zagrażających wizerunkowi i reputacji organizacji oraz konstruowanie strategii przeciwdziałających ich wystąpieniu. Jeżeli sytuacja kryzysowa wystąpi, zarządzanie nią polega na minimalizowaniu skutków kryzysu mogącego zagrażać wizerunkowi i reputacji organizacji. Zarządzanie sytuacją kryzysową oznacza myślenie o wizerunku i reputacji w trzech wymiarach, gdzie pierwszy rozumiany jest jako prewencja, drugi oznacza działania bieżące, a trzeci przygotowuje dobry punkt wyjścia do działań organizacji po rozwiązaniu sytuacji kryzysowej”.

\section{Zarządzanie sytuacjami kryzysowymi w przestrzeni social mediów}

Podczas zarządzania sytuacjami kryzysowymi w przestrzeni mediów społecznościowych istotnym zagadnieniem jest poziom atrybucji odpowiedzialności podmiotu za zaistniałą sytuację.

Rysunek 1. Typologia sytuacji kryzysowych według W.T. Coombsa

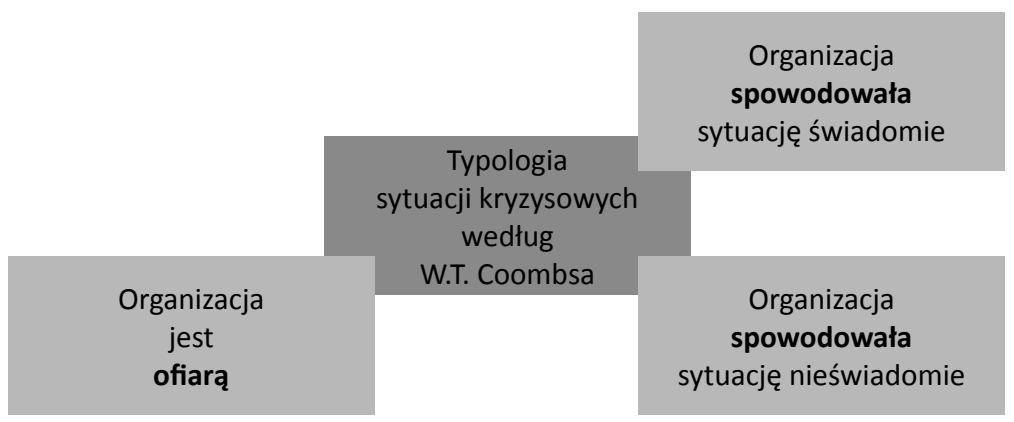

Źródło: opracowanie własne na podst. Coombs 2007, s. 167.

Podążając za typologią sytuacji kryzysowych W.T. Coombsa ${ }^{6}$ - według teorii sytuacyjnego komunikowania się $\mathrm{w}$ kryzysie (situational crisis communication theo$r y$, SCCT) - sytuacje kryzysowe można podzielić w zależności od postawy prezentowanej przez podmiot oraz zagrożeń dla jej reputacji, które są związane z tymi postawami. Przyjmując taką optykę, Coombs zaproponował następujący podział:

1. Podmiot jest ofiarą sytuacji kryzysowej.

2. Podmiot wywołał sytuację kryzysową nieświadomie.

3. Podmiot wywołał sytuację kryzysową świadomie.

5 Tamże, s. 55.

6 W.T. Coombs, Protecting Organizational Reputations during a Crisis: The Development and Application of Situational Crisis Communication Theory, „Corporate Reputation Review” 2007, nr 10(3), s. 167. 
Sytuacja pierwsza - podmiot jest ofiara sytuacji kryzysowej - zakłada niski poziom atrybucji odpowiedzialności za zaistniałe wydarzenia. Jest to o tyle korzystne, że otoczenie podmiotu jest w stanie okazać empatię, zrozumieć, przyjąć wyjaśnienia, a czasami włączyć się w rozwiązywanie sytuacji. Jeśli nie zajdą dodatkowe niekorzystne okoliczności, przyjmuje się, że zagrożenie dla reputacji jest minimalne.

W drugim przypadku - podmiot wywołał sytuacje kryzysowa nieświadomie wiele zależy od kontekstu zaistniałej sytuacji. Przyjmuje się, że otoczenie podmiotu jest skłonne przypisywać mu minimalny poziom atrybucji odpowiedzialności, a zagrożenie dla reputacji jest umiarkowane.

Natomiast trzeci wariant - podmiot wywołał sytuację kryzysowa świadomie - zakłada stan, w którym otoczenie przypisuje podmiotowi wysoki stopień atrybucji odpowiedzialności za zaistniałe wydarzenia. Wobec tego zagrożenie dla reputacji podmiotu można uznać za istotnie zagrożone.

Trzy powyższe grupy sytuacji w naturalny sposób będą wykorzystywać odpowiednie środki zarządcze - im niższy poziom atrybucji odpowiedzialności podmiotu, tym zobowiązania wobec otoczenia będą mieć niższą skalę. To, co kluczowe w zarządzaniu sytuacją kryzysową związaną z hejtem, to fakt, że hejt może zarówno stanowić przyczynę eskalacji zdarzeń kryzysowych, jak i stać się elementem kryzysu wtórnego jako skutek niewłaściwego zarządzania wcześniejszym kryzysem. Kolejny aspekt to prawdopodobna korelacja między skalą atrybucji odpowiedzialności według typologii Coombsa a możliwością wystąpienia sytuacji kryzysowej związanej z hejtem.

\section{Hejt w przestrzeni komunikacyjnej wobec podmiotu}

Hejtem (ang. hate - nienawidzić) określa się agresywne (ze względu na formę), naruszające prawo i pozbawione merytorycznych argumentów różnorodne formy wypowiedzi on-line. W przestrzeni mediów społecznościowych może on przybierać formę tekstową (komentarze, posty, wpisy na blogu itp.), graficzną (np. memy) lub wideo. Przy kwalifikowaniu komunikatu jako hejt istotna jest refleksja nad rozgraniczeniem między hejtem a krytyką oraz świadomość, że aby przekaz był hejtem, nie musi zawierać wulgaryzmów.

Skutki wywołane przez hejt mogą występować w postaci bieżących problemów, ale także być przyczyną zaistnienia warunków sprzyjających do rozwoju sytuacji kryzysowej.

Tematyka hejtu może być związana ze stopniem relacji grup otoczenia (otoczenie wewnętrzne lub zewnętrzne ze szczególnie silnie zaznaczonymi trzema obszarami hejtu wobec podmiotu: (1) nieprawdziwe informacje na temat firmy, (2) hejt ze strony obecnych lub byłych zatrudnionych, (3) tzw. szybkie reklamacje - pojawiające się w sieci informacje opisujące wadliwe produkty lub źle świadczone usługi). Pod względem relacji $z$ otoczeniem (wewnętrznym lub zewnętrznym) tematyka hejtu może być: 
Rysunek 2. Typologia hejtu ze względu na tematykę, podmiot hejtingu oraz jego autora

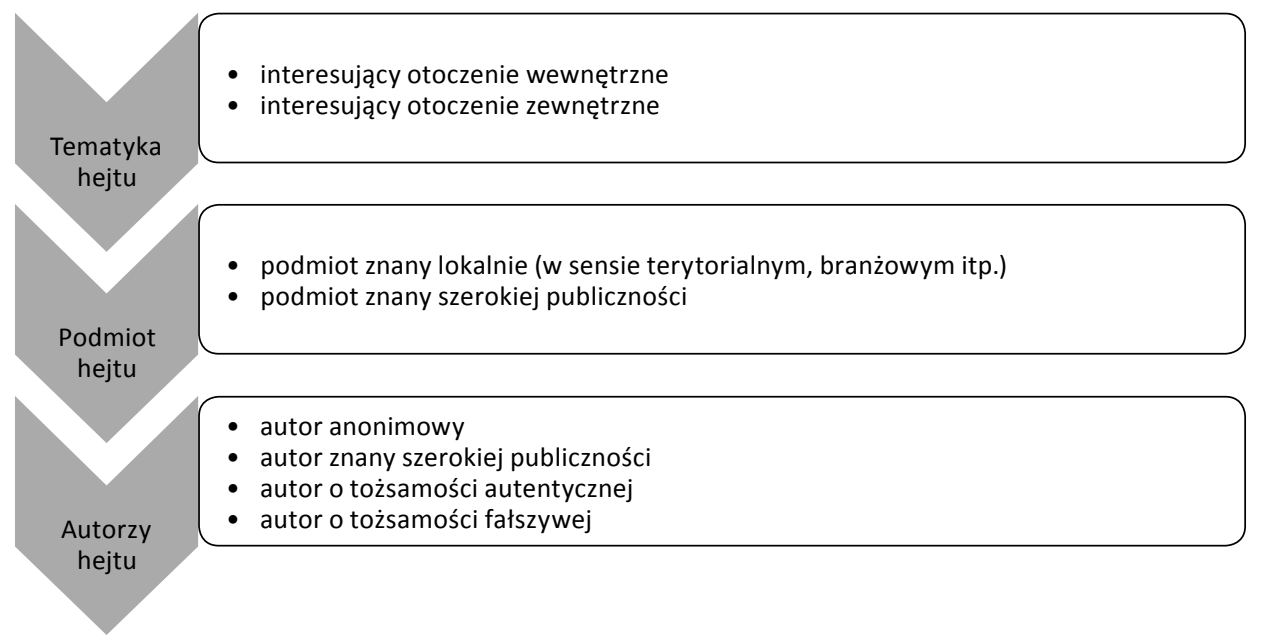

Źródło: opracowanie własne.

1. Interesująca dla otoczenia wewnętrznego - przeważnie temat mniej kontrowersyjny, wywołujący niższe zaangażowanie i niższy poziom emocji, istotny dla wąskiej grupy zainteresowanych, większa szansa wygaszenia bez przedostania się do mediów instytucjonalnych.

2. Interesująca dla otoczenia zewnętrznego - temat przeważnie angażujący szeroką społeczność, znacznie angażujący otoczenie podmiotu, wywołujący silne (czasami skrajne) emocje; tematyka mająca szansę przeniknąć do mediów instytucjonalnych, co tym samym potencjalnie zwiększa ryzyko wystąpienia sytuacji kryzysowej.

Ze względu na podmiot hejtu można zauważyć, że różny może być jego zakres:

1. Podmiot może być znany lokalnie (w sensie terytorialnym, branżowym itp.) - potencjalnie siła hejtu może być niższa, czas agresji krótszy, mniejsze zainteresowanie otoczenia, w tym mediów. Lokalność podmiotu (jeśli jego reputacja była dobra, pozytywna) może stanowić jego przewagę i siłę w walce $\mathrm{z}$ hejterem, ponieważ podmiot w lokalnym środowisku może mieć większą rozpoznawalność, wiarygodność, budzić empatię, mieć bliższe relacje ze swoim otoczeniem niż podmiot o szerokiej skali rozpoznawalności.

2. Podmiot może być znany szerokiej publiczności ${ }^{7}$, co zwiększa prawdopodobieństwo zaliczenia go do grona celebrytów, osób publicznych, pracowników zawodów wolnych itp. W zależności od dotychczasowej reputacji rozpoznawalność może stanowić zaletę lub wadę (dobra, pozytywna będzie wzbudzać

7 Por. D. Tworzydło, Public relations praktycznie, Newsline Sp. z o.o., Rzeszów 2017, s. 211-212. 
zrozumienie i empatię wobec podmiotu, negatywna reputacja podmiotu może jednak wpływać na budowanie swoistego zrozumienia dla hejtu - „należało się"). W przypadku podmiotu o szerokiej rozpoznawalności może także wystąpić sytuacja pojawienia się opisywanej przez Danah Boyd tzw. niewidocznej publiczności (networked public), która gromadzi się w przestrzeni mediów społecznościowych, aby przy zaistnieniu określonych warunków być wręcz sprzyjającym środowiskiem dla dystrybucji treści hejtera ${ }^{8}$.

Odnosząc się do trzeciego kryterium - ze względu na autorów hejtu - można zauważyć, że komentarze tworzone są przez podmioty o różnych profilach tożsamości. Mogą to być:

1. Autorzy anonimowi, często korzystający z poczucia anonimowości on-line.

2. Autorzy znani szerokiej publiczności - czasami nie dość, że znani szerokiej publiczności, to dodatkowo mogący być tzw. liderami opinii.

3. Autorzy o tożsamości autentycznej - występujący w mediach społecznościowych pod swoim imieniem i nazwiskiem, często z oznaczeniem reprezentowanej instytucji.

4. Autorzy o tożsamości fałszywej - próbujący wykorzystać możliwość tworzenia fałszywych kont stanowiących zasłonę dla działań hejtera.

W przypadku autorów anonimowych oraz o fałszywej tożsamości może zachodzić zjawisko stosowania tzw. mimikry komunikacyjnej on-line oraz mimezji komunikacyjnej on-line. Mimikra komunikacyjna on-line definiowana jest jako działania w obszarze komunikacji on-line wykonywane przez podmioty o ukrytej lub fałszywej tożsamości mające na celu wywołanie określonego zachowania lub przekonania grup społecznych, do których kierowane są przekazy. Z kolei mimezja komunikacyjna on-line polega na wytwarzaniu nieautentycznego środowiska $\mathrm{w}$ obszarze komunikacji on-line. Celem takich działań jest prowadzenie nieetycznej komunikacji z zamiarem dyskredytacji marki, produktu, usługi, osoby czy organizacji, przeciwko której realizowane są wspomniane działania?

\section{Hejt a zarządzanie sytuacją kryzysową podmiotu}

Z perspektywy zarządzania sytuacją kryzysową istotne będą skutki mogące być spowodowane hejtem, które w zależności od intensywności i skuteczności działań hejtera mogą wpływać i negatywnie oddziaływać na działania podmiotu, zarówno bieżące, jak i te w długiej perspektywie.

8 Por. M. Kaczmarek-Śliwińska, Zarządzanie komunikacją kryzysowa w przestrzeni mediów społecznościowych w kontekście zjawiska hejtingu, „Kultura - Media - Teologia” 2016, nr 25, s. 46-58.

9 M. Kaczmarek-Śliwińska, Public relations w przestrzeni mediów społecznościowych. Działania organizacji i jej pracowników, Wydawnictwo Uczelniane Politechniki Koszalińskiej, Koszalin 2013, s. 63-66. 
Rysunek 3. Skutki hejtu w kontekście zarządzania sytuacją kryzysową podmiotu

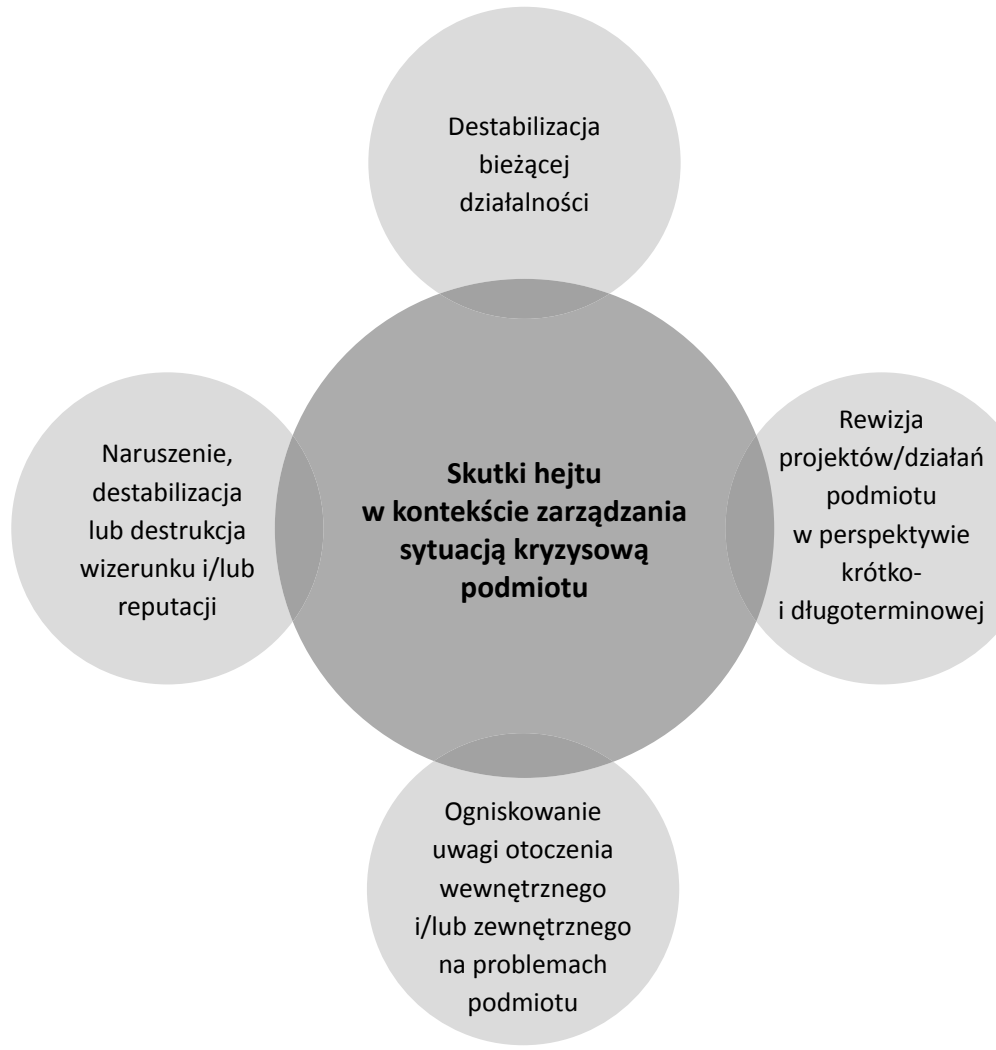

Źródło: opracowanie własne.

Po przeanalizowaniu zjawiska hejtu w kontekście zarządzania sytuacją kryzysową, zauważalne są skutki mogące stanowić zarzewie rozwijającego się kryzysu:

1. Podstawowym postepowaniem w przypadku działań hejtera wobec podmiotu jest analiza, monitoring i podjęcie działań zaradczych. W zależności od skali zaangażowania środków podmiotu (zasobów ludzkich, środków finansowych) może to wpłynąć na destabilizację bieżącej działalności.

2. Działania hejtera - szczególnie te o wysokiej intensywności i dotkliwe - mogą wpływać na korektę planów działalności podmiotu. W zależności od czasu trwania ataków hejtera podmiot może dokonać rewizji planów zarówno krótko-, jak i długoterminowych (czasowe zawieszenie, rezygnacja, odsunięcie w czasie), co z kolei może skutkować obniżeniem wartości finansowej działań podmiotu i wpłynąć na kondycję finansową (obniżenie kondycji finansowej może stanowić kolejne zagrożenie sytuacją kryzysową i przejściem w stan kryzysu wtórnego).

3. Hejt może zwrócić uwagę na problemy podmiotu. Sytuacje trudne, problematyczne, kłopoty są szczególnie interesujące dla hejtera, a jego działania 
ogniskujące uwagę użytkowników mediów społecznościowych mogą mieć także przełożenie na zainteresowanie mediów instytucjonalnych ${ }^{10}$. Podmiot $\mathrm{w}$ takich sytuacjach stara się przekazywać otoczeniu komunikaty objaśniające sytuację, ale nie pokazujące strategii działania. Ten moment może stanowić pole działań hejtera, który - czasami przybierając wręcz pozę zgłębiającego sprawę, dociekliwego internauty - będzie uzasadniał i racjonalizował swoje poczynania. Podobny problem może wystąpić wówczas, gdy podmiot $\mathrm{w}$ sytuacji trudnej czy kryzysowej w kontaktach $\mathrm{z}$ otoczeniem wewnętrznym i zewnętrznym przyjmie zasadę blokowania informacji. Wówczas może doprowadzić do powstania tzw. luki informacyjnej, czyli różnicy między informacjami dostarczonymi przez podmiot a oczekiwaniami mediów instytucjonalnych oraz użytkowników mediów społecznościowych. Podczas sytuacji kryzysowej osoby zarządzające starają się, aby jednym z działań było wyciszanie problemu, uspokajanie nastrojów, minimalizacja emocji, natomiast działania hejtera będą przynosić odwrotne efekty. W skrajnie niesprzyjających warunkach może to doprowadzić do eskalacji sytuacji kryzysowej, przeniesienia jej na inne obszary działania organizacji czy też szerokiego oddźwięku w mediach społecznościowych i instytucjonalnych.

4. Hejt może spowodować również reperkusje w sferze wizerunku podmiotu. Jeśli podmiot będzie narażony na działanie hejtera w krótkim okresie, może to wpłynąć na postrzeganie podmiotu w otoczeniu wewnętrznym lub zewnętrznym (w zależności od typu sytuacji kryzysowej). Długotrwała działalność hejtera może spowodować destabilizację lub destrukcję wizerunku, a w skrajnie długich okresach oddziaływać także na reputację podmiotu. Zarówno krótko-, jak i długotrwałe obniżanie potencjału wizerunku może skutkować między innymi utratą wiarygodności i mieć przełożenie na działania podejmowane przez podmiot w ramach współpracy zewnętrznej (np. utrata projektów, utrata partnerów projektów, brak beneficjentów programów realizowanych przez podmiot).

\section{Sposoby reagowania na hejt przez podmioty nim dotknięte}

Rozważając sposoby reagowania na działania hejetra, należy uwzględnić fakt, że każda sytuacja kryzysowa posiada swoją specyfikę, odrębność, kwestie indywidualne. Nawet jeśli pozornie sytuacje kryzysowe są tego samego typu, działania zarządcze każdorazowo powinny uwzględniać indywidualizm i kontekst sytuacji.

10 Kevin Murray, specjalista w zakresie komunikacji strategicznej oraz zarządzania reputacją, określił taką sytuację słowami: „Ciągły nadzór opinii publicznej jest coraz bardziej intensywny. To się nie zmieni. Trzeba się nauczyć z tym żyć”. K. Murray, Język liderów, JS \& Co. Dom Wydawniczy, Ożarów Mazowiecki 2014, s. 54. 
W zależności od pozycji podmiotu, typu sytuacji kryzysowej, intensywności działań hejtera, kontekstu społecznego i innych czynników można rozważyć podejmowanie następujących działań:

1. W sferze prewencji:

a. Stałe prowadzenie monitoringu mediów instytucjonalnych oraz mediów społecznościowych pozwalające na wczesne wykrycie sygnałów ${ }^{11}$ mogących świadczyć o zwiększonym zainteresowaniu podmiotem oraz o większej liczbie wpisów zawierających przekazy zmierzające od krytyki w stronę hejtu.

b. Odpowiednie zarządzanie działalnością podmiotu - bieżące rozwiązywanie problemów, prowadzenie polityki otwartości.

c. Szkolenia podmiotu w zakresie social media policy (aktywności on-line), co pozwala na uwrażliwienie w zakresie konstruowania przekazów i prowadzenia komunikacji na obniżonym poziomie ryzyka kryzysowego.

d. Uwzględnienie sytuacji kryzysowych wynikających $\mathrm{z}$ ataków hejterskich w procedurach zarządzania sytuacjami kryzysowymi (manual ZSK).

e. Regularne audyty ${ }^{12}$ w zakresie ryzyka sytuacji kryzysowej związanej $\mathrm{z}$ agresją elektroniczną, w tym między innymi $\mathrm{z}$ atakami hejterskimi.

2. W sferze działań w sytuacji kryzysowej dotyczącej hejtu:

a. Przekazanie prowadzenia sprawy osobom odpowiedzialnym za wdrożenie działań kryzysowych wewnątrz podmiotu lub ekspertom zewnętrznym (znacznie obniża to poziom zaangażowania, dając możliwość wyeliminowania podejmowania decyzji opartych na emocjach). Pozwala to zachować zasadę ,jednego głosu” podmiotu oraz spójności przekazu.

b. Konsultacje prawne.

c. Wydanie komunikatu - lecz bez wchodzenia w dialog z hejterem - odnoszącego się w sposób syntetyczny do ataków hejtera z jednoczesnym zaproszeniem do kontaktu zainteresowane strony (media instytucjonalne, użytkowników mediów społecznościowych, liderów opinii czy samego hejtera). Taka postawa świadczy o otwartości, chęci wyjaśnienia zarzutów oraz pokazuje standard kultury.

d. W przypadku, gdy atak hejtera wskazuje na chwilową działalność, można przyjąć zasadę braku „widocznej” (dla otoczenia wewnętrznego lub zewnętrznego) reakcji w zamian za podejmowanie działań „w tle”, unikanie komentowania (szczególnie $\mathrm{w}$ sytuacji, gdy hejter nie podaje

11 D. Tworzydło, Zarzadzanie w kryzysie wizerunkowym, Difin SA, Warszawa 2019, s. 103-104.

12 Por. J. Kończak, P. Bylicki, Marka korporacyjna i jej komunikacja, Wydawnictwo Public Dialog, Warszawa 2018, s. 287-312; A. Miotk, Nowy PR. Jak Internet zmienit public relations, Wydawnictwo Słowa i Myśli, Lublin 2016, s. 245-263; M. Kaczmarek-Śliwińska, Internet Public Relations. Polskie realia działań public relations $w$ Sieci, Wydawnictwo Uczelniane Politechniki Koszalińskiej, Koszalin 2010, s. 123-124. 
prawdziwych danych personalnych), oświadczeń, co daje szansę na wyciszenie tematu.

e. Przesunięcie uwagi odbiorców na inny temat.

f. Jeśli atak hejtera związany jest $\mathrm{z}$ profilami podmiotu $\mathrm{w}$ mediach spolecznościowych, wezwanie hejtera do usunięcia wpisów (opierając się na funkcjonujących regulaminach mediów społecznościowych oraz stanie prawnym).

g. Jeśli atak hejtera wystąpił poza profilami podmiotu w mediach społecznościowych (np. na fanpage’ach mediów lub profilach innych użytkowników), wezwanie administratorów kont objętych atakiem hejtera do usunięcia wpisów czy zablokowanie możliwości dodawania komentarzy (to ostatnie działanie warto podejmować w przypadku tematów jedynie bardzo kontrowersyjnych, które w sposób automatyczny mogą generować ataki hejterskie).

h. Podjęcie kroków prawnych: zawiadomienie organów ścigania o podejrzeniu popełnienia przestępstwa zniesławienia, zniewagi lub groźby karalnej. Za te przestępstwa grozi grzywna, kara ograniczenia wolności lub pozbawienia wolności do roku (w przypadku groźby karalnej kara pozbawienia wolności do dwóch lat).

\section{Podsumowanie}

Przywołana we wprowadzeniu brutalizacja dyskursu przestrzeni publicznej staje się faktem. Mimo podejmowanych akcji społecznych czy pojawiających się w mediach dyskusji (czasami będących skutkiem negatywnych lub tragicznych zdarzeń, jak to było po zabójstwie prezydenta Gdańska Pawła Adamowicza) nie można zauważyć poprawy dającej szansę na trwałe polepszenie sytuacji.

Wejście podmiotów różnego typu w drugą dekadę funkcjonowania mediów społecznościowych w przestrzeni medialnej pokazuje, że hejt stanowi jeden z jej elementów. Trudno zakładać, że wzmacnianie uregulowań prawnych czy akcje edukacyjne i kampanie społeczne pozwolą na całkowitą eliminację tej formy agresji elektronicznej. Dlatego też warto podejmować działania zarządcze z perspektywy podmiotu polegające z jednej strony na działaniach prewencyjnych, z drugiej zaś na opracowaniu i wdrożeniu procedur na czas realnego postępowania w obliczu sytuacji kryzysowej.

Jak zaznaczono w treści artykułu, istotna jest świadomość podmiotu na temat możliwości zarządzania w obszarze sytuacji kryzysowej wynikającej z ataku hejterskiego. Należy również zauważyć, że ataki hejterskie mogą być związane z działalnością podejmowaną przez podmiot i wynikającymi z tego potencjalnymi sytuacjami kryzysowymi. Dlatego przydatnym narzędziem okazuje się typologia zarządzania sytuacjami kryzysowymi w przestrzeni mediów społecznościowych W.T. Coombsa zakładająca trzy poziomy atrybucji odpowiedzialności podmiotu. 
Uwzględnienie $\mathrm{w}$ tak określonym środowisku specyfiki hejtu ze względu na jego tematykę, podmiot hejtu i autora oraz właściwe określenie przewidywanych skutków hejtu w kontekście zarządzania sytuacją kryzysową podmiotu pozwala dobrać odpowiednią strategię działań, która daje szansę na minimalizację skutków ataku agresora-hejtera.

\section{Bibliografia}

Coombs W.T., Protecting Organizational Reputations during a Crisis: The Development and Application of Situational Crisis Communication Theory, „Corporate Reputation Review”, 2007, $\mathrm{nr}$ 10(3).

Kaczmarek-Śliwińska M., Internet Public Relations. Polskie realia działań public relations $w$ Sieci, Wydawnictwo Uczelniane Politechniki Koszalińskiej, Koszalin 2010.

Kaczmarek-Śliwińska M., Public relations organizacji w zarządzaniu sytuacjami kryzysowymi organizacji. Sztuka komunikowania się, Difin, Warszawa 2015.

Kaczmarek-Śliwińska M., Specyfika zarządzania sytuacja kryzysowa w przestrzeni mediów społecznościowych $w$ perspektywie typologii Situational Crisis Communication Theory W.T. Coombsa, „Studia Medioznawcze” 2019, nr 4(79), s. 318-332.

Kaczmarek-Śliwińska M., Zarządzanie komunikacją kryzysowa w przestrzeni mediów społecznościowych w kontekście zjawiska hejtingu, „Kultura - Media - Teologia” 2016, nr 25, s. $46-58$.

Kończak J., Bylicki P., Marka korporacyjna i jej komunikacja, Wydawnictwo Public Dialog, Warszawa 2018.

Miotk A., Nowy PR. Jak Internet zmienił public relations, Wydawnictwo Słowa i Myśli, Lub$\operatorname{lin} 2016$.

Murray K., Język liderów. JS \& Co. Dom Wydawniczy, Ożarów Mazowiecki 2014.

Tworzydło D., Public relations praktycznie, Newsline Sp. z o.o., Rzeszów 2017.

Tworzydło D., Zarządzanie w kryzysie wizerunkowym, Difin SA, Warszawa 2019.

\section{Netografia}

https://biznes.newseria.pl/news/hejt-staje-sie-duzym,p120478802 (dostęp: 2.05.2019). 